This extract is taken from the author's original manuscript and has not been edited. The definitive version of this piece may be found in Jewish Identity in Western Pop Culture by Jon Stratton which can be accessed from www.palgrave.com 
(A slightly revised version of this essay appeared in Jon Stratton Jewish Identity in Western Pop Culture: The Holocaust and Trauma through Modernity Palgrave

Macmillan, 2008.)

\section{Why Were the Sixties so Jewish?}

Einstein, disguised as Robin Hood

With his memories in a trunk

Passed this way an hour ago

With his friend, a jealous monk

Bob Dylan “Desolation Row.”

I need to start with a caveat. This is not a historical trainspotting chapter about who was Jewish in the American counterculture of the sixties. As we shall see, a high proportion of identifying Jewish college students was engaged in radical political activity. More, a remarkably high percentage of Jews, as compared to their presence within the general population, were leaders in the political and socio-political arena. ${ }^{1}$ Indeed, Jews were central to areas of activism as diverse as Students for a Democratic Society (SDS), the Weathermen, the Diggers, the Yippies, the second wave feminist movement, the protest movement in folk-rock music.

Jews also played a very important role in the Civil Rights movement. Indeed, as Jonathan Kaufman notes, “[b]y the mid-1960s, Jewish contributors made up threequarters of the money raised by SNCC [Student Nonviolent Coordinating Committee], CORE [Congress of Racial Equality], and SCLC [Southern Christian Leadership Conference].”2 However, in a crucial development, not only for its practical consequences but for what it suggests about the changing discursive context in which 
African-Americans and Jews related to each other, an SNCC staff meeting in December 1966, with Stokely Carmichael as chairman, voted to exclude all whites, which included Jews, from the organization. ${ }^{3}$ This marks an important watershed, and one I will discuss in more detail because it signals the repositioning of Jews in American society; a repositioning which, as we shall see, was central to Jewish involvement in the counterculture and, to some extent, to the existence of the counterculture itself.

In this chapter, then, I am not interested in the role of individuals as such: Al Haber, Bob Ross, Todd Gitlin, for example, in SDS; Peter Berg and Peter Coyote in the Diggers; Abbie Hoffman and Jerry Rubin in the Yippies; Betty Friedan (a little older), Robin Morgan, Gloria Steinem, Kim Chernin, Marge Piercy to name a very few in the women’s movement; Phil Ochs, Bob Dylan, Paul Simon and Art Garfunkel in folk music. All these people, and more, will appear in this chapter. Many, many more won’t. It will be easy to list Jews in the counterculture that I don’t mention. That is not the point. This is not a history of the roles that Jews played in the events that are now thought of as making up "the Sixties" in the United States. Rather, my concern is with why, proportionally, so many Jews in the United States were involved in the counterculture and, to some extent, how their Jewish interests, not necessarily consciously, came to shape the preoccupations, and style, of the counterculture.

\section{So Many Jews}

Let us be more specific. Arthur Liebman, in his history of Jewish involvement in the American Left, Jews and the Left, writes that during the 1960s "the number of Jews among American college students averaged about 325,000 a year.”4 SDS, the major campus radical-left organization of the 1960s, evolved out of the student wing of the League for Industrial Democracy. LID had been set up in the early part of the century as a socialist, and indeed anti-communist, group allied to the Socialist Party. By the late 
1950s it, and its student adjunct, were more or less moribund. ${ }^{5}$ Liebman tells us that: "In the early to mid-1960s, during which time membership of SDS rose from 250 to more than 30,000 , the percentage of Jews within it was considerable, ranging from 30 to 50 percent." ${ }^{6}$ In the second half of the 1960s, SDS membership neared 100,000 but, Liebman writes, "the percentage of Jews declined."7 This relative decline in Jewish involvement is, I would suggest, easily explained by reference to the total number of Jews on the campuses. The high proportion of this number involved seems to have remained pretty constant. Perhaps the more telling point is that: “Jews were . . . almost always a significant proportion of the leaders and activists within SDS. At the 1966 SDS convention 46 percent of the delegates who identified themselves as having a particular religious background were Jewish.”8

Of the Weathermen, the radical-left terrorist group that grew out of the implosion of SDS, Liebman writes that one-third of those arrested by the police were Jewish. ${ }^{9}$ Peter Collier and David Horowitz, in their right-wing critique of the Sixties' generation, Destructive Generation, comment that WASPs were:

attracted to the Jewish drama of the new group and to "struggle sessions" during which Rudd, Robbins, and J.J. histrionically argued their positions. (Typical of the hard style she was developing, Bernadine [Dohrn] now called herself an “Oven Jew” explaining that she only identified with her Jewish side through the knowledge that when the inevitable new genocide began, her Jewish blood would mark her as a victim. $)^{10}$

Dohrn was Jewish on her father's side. Her preoccupation with what, in the 1970s, would become conventionally known as the Holocaust, was by no means unusual for these radical Jews and is a theme to which we shall return. 
At the Berkeley campus of the University of California, the first spark that ignited the Free Speech Movement was the protest at the House of Un-American Activities Committee (HUAC) sitting in San Francisco's City Hall on $13^{\text {th }}$ May $1960 .^{11}$ The fire really started on the Berkeley campus itself in 1964 when the university administration restricted left-wing political activity on the campus. Liebman writes that: “[a] majority of the FSM's leadership (Steering Committee) was Jewish',12 and that, in 1964, 'about onethird of the Free Speech Movement (FSM) demonstrators were Jews.”13 More generally, Liebman explains that "ninety percent of Jewish students attending schools at which there were demonstrations claim to have participated"14 and that, "Overall, in the course of the decade, it has been estimated that from one-third to one-half of the most committed activists at the most volatile schools were Jews." ${ }^{15}$

For Liebman, the Jews of the New Left were carrying on a family tradition. He argues that, regardless of their middle-class background, in left-wing schools, summer camps, and resorts, institutions set up by the Jewish community, "young Jewish boys and girls were either politically socialized in conformity with the attitudes and values of their parents, or they were provided with exposure to a political perspective that reinforced that of their parents.” ${ }^{16}$ While such institutions played a part, I will argue that, far more important, was the ambiguous social position in which Jews of the third generation since migration from the Pale found themselves during the 1950s and 1960s. Finally accepted as "white," they nevertheless still experienced discrimination in a multitude of mostly subtle ways. Moreover, while their parents had in the main joined the liberal middleclass, the effect of discrimination, coupled with a still almost unspoken, folk knowledge of the events of the Holocaust, meant that these Jews, in spite of their assimilation into the culture, and values, of Anglo-American, “white” life, held themselves apart. At the same time, these third generation Jews felt a disillusionment with an American life which, with 
its ideology of individualism and egalitarianism, failed to deliver. This was particularly shocking, consciously or not, for children of religious, or for that matter secular, Jewish families which, in one form or another, the mitzvah of tzedekah, which we might translate here as "righteous acts," was a part of life. What I am suggesting is that, for Jews, with their religio-cultural concern with an ethics of social practice, a society in which the ideological promise so clearly outstripped the way life that was led was a society in need of social transformation.

I want to begin unpacking this argument by looking at the problem of generations. These Jews of the Sixties were, in the way they experienced America if not in actuality, third generation, the grandchildren of those Yiddish-speaking Jews who migrated from the Pale to the United States around the turn of the century. As Arnold Eisen writes:

That a Jew coming to maturity in 1930 could . . . be called "second generation" is a function of the massive immigration of Jews from Eastern Europe between 1880 and 1924 which raised the Jewish population of the United States from about a quarter million in 1880 to 4.2 million in $1927 .^{17}$

One aspect of Jewish transformation over these three generations was the assimilatory, syncretic accommodation with American ideology.

In one respect Jews found a remarkable overlap between that ideology and their own religio-cultural thinking:

In choosing America the Jews had adopted a nation which, thanks to a Puritan legacy deriving from the Hebrew Bible, has traditionally regarded itself as a chosen people and its bountiful country as a chosen land. Americans, Jews discovered, saw themselves as a people destined to build a “city on a hill” after traversing a great wilderness. ${ }^{18}$ 
This enabled Jewish accommodation to be far-reaching. Reform Judaism, the most important sect for the second generation, began in France and Germany in the early nineteenth century as an accommodation to the needs of modern society. Imported to the United States by migrating German Jews, it was formalized in the Pittsburgh Platform of 1885. Underpinning the Jewish-American turn to Reform Judaism was a perception of fundamental similarities between Judaism and secular American ideology. This claim to similarity, if not homology, is exemplified in the 1937 revision of Reform known as the Columbus Platform which also showed the influence of the more traditional Jews of the first generation in its return to many long-established Jewish practices. Nevertheless, the primary emphasis in Reform is on ethics. In 1952, in a speech before the Central Conference of American Rabbis, the organized rabbinate of Reform, Nelson Glueck, soon to become president of the Hebrew Union College, said:

Here, in the New Jerusalem of America planned as a spiritual Zion by its founding fathers and brought into being by revolutionary patriots imbued with the Godinspired liberalism of the prophets of Israel, the concept of this country as a citadel of social justice and warm-hearted humanitarianism was a natural one. ${ }^{19}$

As Eisen points out, Glueck was clear that Reform Judaism equated with American liberalism, indeed with American democracy. Specifically, in this quotation we find an assertion of the similitude of American and Jewish understandings of social justice.

\section{Social Justice}

It is necessary, here, to say something about this idea of social justice. Earlier, I mentioned that the mitzvah of tzedekah could be translated as "righteous acts." The idea derives from Deuteronomy 16:20 “Justice, justice shall you pursue.” As a divinely ordained imperative, tzedekah is often translated as "charity" and thought of in those 
modern, western terms, as the obligation to give of one’s bounty to help other Jews, and others in general, who are in more straitened circumstances. Over the first two generations in the United States, this understanding was transformed. Deborah Dash Moore has described how, in the nineteenth century, the concept of charity was parlayed into the idea of philanthropy by way of the Protestant notion of stewardship. ${ }^{20}$ As Jews syncretically reworked the imperative of tzedekah with the idea of philanthropy so:

From a social activity of wealthy individuals, philanthropy became a communal endeavor. As a collective enterprise, Jewish philanthropy tried to reach across class lines to unite Jews into a non-sectarian community of interests with moral dimensions. $^{21}$

At the same time the second generation synthesized American and Jewish world-views. As Moore writes:

Standing between the immigrants and future American generations of Jews, the second generation created a communal framework for its children. They constructed a moral community with supports borrowed from American culture, middle-class values, urban lifestyles, as well as from their immigrant Jewish heritage. In fact, so successful were they in binding middle-class norms to visions of Jewish fulfilment, that their children could often not disentangle the two. ${ }^{22}$

Exactly. Thus, for the third generation, tzedekah was understood in a secular context. Where the second generation saw it as a moral force binding the community, the third generation grew up to understand it in universalist terms, the terms of the Enlightenment on which Anglo-American national ideology was founded, as “social justice.”

Here we can return to Glueck’s typically second generation understanding of the United States as a morally just society. It was their disillusionment with this perception, 
based on a variety of realizations, that initiated the radicalism of the third generation. We may start contextualising this by turning to Dominick Cavallo’s discussion of "white” involvement in the Civil Rights movement. Cavallo writes that:

Most whites who joined SNCC or participated in the sit-ins, boycotts, freedom rides and voter-registration drives of the early sixties, were children of liberal, middle-class parents. Whatever their family backgrounds (not all of them were offspring of middle-class or liberal parents), these young people were inspired by moral outrage. The injustice and inhumanity of racism inspired them to go to the South and "put their bodies on the line."23

Cavallo’s book is remarkably race-blind. Liebman tells us that:

In the summer of 1961 Jews made up two-thirds of the white Freedom Riders that travelled into the South to desegregate interstate transportation. Three years later Jews comprised from one-third to one-half of the Mississippi Summer volunteers. $^{24}$

I have already referred to the very high proportion of the funding of Civil Rights organizations that came from Jewish sources. This, we can now understand as a more conventional form of tzedekah.

Disillusionment started at home. Here, for example, is the Civil Rights worker and feminist Melanie Kaye/Kantrowitz writing about her Jewish family:

Every day I watched my parents leave our Brooklyn apartment to take the subway to work and return home drained, and I, with my seventeen-year-old energy, vowed to live differently. I believed I was confronting my parents' hypocrisy; in truth, I was also punishing them. These were their values? Then I would live these values, scorn their inability to do the same. ${ }^{25}$ 
Kaye/Kantrowitz expresses her disgust, her moral outrage, at her parents' failure to live up to their own values in a society that was also failing to live up to the values it claimed. The basis of this relation is the assumed homology of values of Jews/Judaism and American ideology exemplified for the second generation in Glueck’s assertion.

Abbie Hoffman, the activist and co-founder of the Yippies tells a similar story in his autobiography, Soon To Be a Major Motion Picture: “Deep down I’m sure we felt our parents' generation was a bunch of cop-outs. Six million dead and except for the Warsaw ghetto hardly a bullet fired in resistance!”26

Hoffman tells a story of being very young and practice-reading the hotel brochure on the drive to the hotel for the family holiday. He asks: "Hey everybody, what does 'Christian Clientele Only' mean?" The upshot is that, rather than confronting the hotelier, Hoffman's father drives to another hotel. Hoffman retrospectively places this episode in the context of the Holocaust and the claim of Jewish passivity in the face of extermination. However, his disgust at his father's failure to confront anti-Semitic discrimination is founded on an assumption of egalitarian social justice the moral correctness of which pervaded Hoffman's later activism, first in the Civil Rights movement and later in various fields including the anti-Vietnam War movement and the Yippies.

Jerry Rubin, who was an anti-Vietnam War activist and subsequently co-founder of the Yippies with Hoffman, cut his radical teeth on the Berkeley FSM. Jonah Raskin writes: "Born in 1938 to a Jewish working-class family in Cincinnati, Rubin grew up an all-American kid."27 Cavallo tells us that Rubin was: "fascinated by the image of the loner cowboy dispensing justice in an anarchic West. He once remarked (tongue only slightly in cheek) that his radical ideas were 'more influenced' by 'the Lone Ranger [television series] than by Mao or Lenin., ,28 
Here we can see well the third generation's cultural starting-point in an assimilatory melding of secularized Jewish values and American ideology. Riv-Ellen Prell discusses the results of Marshall Sklare’s 1957 sociological study of Jewish identity in a Chicago suburb. Ranking first out of twenty-two proffered statements in what respondents felt made a "Good Jew” was "to lead an ethical and moral life," third was "to promote civic betterment and improvement in the community."29

The most important place where we can find this confluence of secularized Jewish and American values, and the third generation's reassertion of these from a disillusioned and left-radical position, is in the now-legendary Port Huron Statement of 1962. This statement was intended as the manifesto of the SDS. James Miller describes it as "one of the pivotal documents in post-war American history.”30 The Statement was drafted by Tom Hayden, perhaps the most significant of the founding members of Students for a Democratic Society. Hayden was born in 1939 in Royal Oak, Michigan, about twelve miles outside of Detroit. His Catholic parents were of Irish descent. ${ }^{31}$ Later, I will discuss the similarities, and divergences, in the American ambiguous racialization of the Irish and the Jews. Here, we can note that Hayden was not the only male of IrishCatholic background prominent in the early formation of SDS. Michael Harrington, twelve years older than Hayden, was the link between LID and its student wing. As Todd Gitlin writes,

[a]mong the older, largely Jewish trade unionists, [Harrington] was the LID’s one younger hope ... . He was close to Hayden, had drunk and travelled with him, had gone to his wedding - they were both fluent-tongued, fervent, middle-class Irish Catholic boys from the mid-West. ${ }^{32}$

It is worth mentioning here that, in San Francisco’s Digger movement, about which more will be said presently, the prime movers were predominantly Jewish and Irish-American. 
Hayden's draft Statement was discussed over three days by the fifty nine delegates at the Port Huron conference, many of whom were Jewish, and subsequently redrafted by Hayden along with Al Haber and Bob Ross, both Jews.

Here are two sentences, subsequently considerably revised and shortened, from a paragraph of a declaration presented to the Central Conference of American Rabbis in 1936. Rewritten, it became part of the Columbus Platform: "The mission of Israel expresses our undying will to live a life of ethical and religious creativeness. Israel will endure as long as its destiny will be bound up with the destiny of faith, brotherhood, freedom, justice, love, truth, and peace.”33 Near the beginning of the Port Huron Statement there is a section entitled "Values." Here we find: "Unlike youth in other countries we are used to moral leadership being exercised by our elders. But today, for us, not even the liberal and socialist preachments of the past seem adequate to the forms of the present."34

We can see, as Moore suggested happened, the seamless synthesis of Jewish and American values. This critique is, simultaneously, third generation disillusion-note the similarity in disappointment with that expressed by Kaye/Kantrowitz and Hoffman in their parents_-and more universally American. Similarly, the left genealogy suggested by the allusion to "liberal and socialist preachments" refers to the history of the American left but at the same time refers to the trajectory of very large numbers of Jewish families in which the first generation's European socialism gave way, under the impact of assimilation and upward social mobility, to the second generation's American liberalism. Allegiance to this liberalism is now being associated with the moral failure of American/Jewish-American society. 
Thus, for Jews, the moral assertion set out in the Columbus Platform draft is here read by the subsequent generation in terms of the second generation's failure to live up to its promise. The Port Huron Statement goes on:

We regard men [sic] as infinitely precious and possessed of unfulfilled capacities for reason, freedom and love. . . . Men have unrealized potential for selfcultivation, self-direction, self-understanding and creativity. . . Human relationships [sic] should involve fraternity and honesty. ${ }^{35}$

Here are reproduced almost all the moral values identified as being central to an ethical life in the Columbus Platform draft: creativity, freedom, love, brotherhood/fraternity, honesty/truth. The very success of the second generation in synthesising Jewish and American values here becomes the basis for a critique of American society, and implicitly of the Jewish-American community, for not living up to those values.

The concept that knitted up this skein of values for both the Americanized Judaism of the second generation and the SDS radicals was democracy. As Eisen writes: In America . . . the primary effort at harmonization was not made in terms of universalism, or even of the "Judeo-Christian heritage," but in terms of democracy, a parallel harmonization which rendered the others, more useful in the past, somewhat dispensable. $^{36}$

For the second generation Jews, democracy encoded a pluralism which allowed for their existence as a community within American society. The third generation radicalized the idea of democracy, calling for "participatory democracy." Cavallo describes it as "one of the most frequently mouthed shibboleths of the decade, though it seemed to have different meanings to each person who used it, including those in SDS.”37 Running their Jewish values as universal, American values, it would seem that, unlike the second generation's 
attempt to make space for Jews within American, representative democracy, ${ }^{38}$ the radicals of the third generation were looking to a form of democracy that celebrated the worth of each individual equally and saw this as the basis for promoting an ethical society.

Miller argues that Hayden's understanding of participatory democracy derived from an article by one of his lecturers at the University of Michigan, the Jewish Arnold Kaufman who, in 1960, had published "Human Nature and Participatory Democracy.”39 Kaufman's argument is fundamentally ethical, concerned with how each individual might reach the limit of their human potential. As he writes: “A democracy of participation may have many beneficial consequences, but its main justifying function is and always has been, not the extent to which it protects or stabilizes a community, but the contribution it can make to the development of human powers of thought, feeling, and action." ${ }^{40}$ The idea of participatory democracy enabled the third generation, and their fellow radicals, simultaneously to take a step further on the assimilatory road and embrace American individualism while using that very individualism as the basis for radical action against the perceived immorality of American society and to attempt to create a new, American community—a classically American quest which, as Cavallo explains, can be traced back to the end of the eighteenth century. ${ }^{41}$

So far I have discussed the third generation's radicalism, indeed their desire to reconstruct American society along more moral lines, in terms of their disillusionment with the second generation's hopeful acceptance of American values. We must now contextualize that disillusionment and the disappointment on which it was founded. Matthew Frye Jacobson, in Whiteness of a Different Color, recounts how:

The period of mass European immigration, from the 1840s to the restrictive legislation of 1924, witnessed a fracturing of whiteness into a hierarchy of plural and scientifically determined white races. ... Finally, in the 1920s and after, 
partly because the crisis of over-inclusive whiteness had been solved by restrictive legislation and partly in response to a new racial alchemy generated by AfricanAmerican migrations to the North and West, whiteness was reconsolidated ${ }^{42}$

Jacobson argues that, having been racialized out of whiteness in the second half of the nineteenth century, Jews were reincorporated from the 1920s onwards. Karen Brodkin asserts that: "The U.S. 'discovery' that Europe was divided into inferior and superior races began with the racialization of the Irish in the mid-nineteenth century.”43

While Jacobson focuses on the massive influx of migrants, Brodkin examines the way American society constructed a racial hierarchy which related to what were considered appropriate jobs for each racial group. In this argument, the racialization of the Jews, along with national groups such as the Italians, had to do with job protection as well, of course, as the protection of Anglo-American culture and, indeed the "white" race itself. The early 1920s saw the popularity of Madison Grant's The Passing of the Great Race, published in 1916, in which he warned against accepting the migrant Jews as white, "the Polish Jew, whose dwarf stature, peculiar mentality, and ruthless concentration on self-interest are being engrafted upon the stock of the nation." ${ }^{44}$

Very many of the Jewish migrants arrived as committed socialists. In fact, John Murray Cuddihy, for one, argues that socialism was developed in Europe, in the first instance, by Jews attempting to address in universalist rhetoric the so-called "Jewish question." 45 For the first generation, as Brodkin writes, in the United States, as, it had been in the Pale, Jewish socialism was a way in which Jews confronted their racialized oppression in a capitalist sociality:

Jewish socialism shared a broad set of principles with the rest of the community: that everyday Jews were members of the working class and were exploited as 
workers; that Jews were stigmatised and discriminated against as a race; that Jewish workers had to organize and fight the bosses and the state for their dues; that the goal of the international work-class struggle was to build a society based on reciprocal principles that fed the mind and spirit ${ }^{46}$

Presented as a universalist ideology, socialism functioned as a secular complement to Judaism as a means of building and preserving community. In addition, it provided a basis for communal action against a racially structured economic environment read in terms of class.

\section{Whitening the Irish and Jews}

In Broken Alliance, Jonathan Kaufman discusses the reasons for the Jewish involvement in African-American struggles for civil rights. Kaufman explains that, in the eighteenth and nineteenth centuries, American Jews were little concerned with Black rights. Indeed,

many Jews supported the institution of slavery. ${ }^{47}$ For Kaufman, the turning point was the Americanization of Judaism as expressed in the Reform's Pittsburgh Platform. As we have seen, it was this Platform which first formalized the American Jewish concern with social justice. Complementing this development in the established community, Kaufman argues for the importance of the socialism of the new migrants:

The catechism of socialism impelled an alliance with blacks. The brotherhood of the workers would overthrow the bosses and banish racism, anti-Semitism, war, and exploitation. Even more, socialism gave Jews an opportunity few could dream of in Poland or Russia - the chance to help people less fortunate than themselves. $^{48}$

The result is well known, from the key roles played by Joel and Arthur Spingarn in the formation of the NAACP [National Association for the Advancement of Colored People], 
to Samuel Leibowitz's defence of the nine “Scottsboro boys” in 1931, to the Jewish involvement, already noted, in the Civil Rights movement of the 1960s.

What is left out of this equation is the importance of the racialization of the Jews. Socialism enabled Jews to make common cause with Blacks because, as we have seen, it was an ideology that came out of the European racialized oppression of the Jews. As importantly, Blacks could make common cause with Jews because they understood that Jews were racialized and discriminated against. The Ku Klux Klan was antisemitic for the same reason it was anti-Black: both races were considered to be inferior. When Liebowitz travelled to Scottsboro from the relative safety of New York it was less than twenty years after Leo Frank had been lynched in 1913 for, it was claimed, murdering (and possibly raping) a white girl. When three Civil Rights workers were murdered in Mississippi in 1964, Mickey Schwerner, Andy Goodman and Jim Chaney, were publicly identified as two whites and a Black. However, it seems too coincidental that, at a time when Jews were supposedly thought of as "white," the only two white Civil Rights workers to be murdered, rather than beaten up, happened to be Jewish. Yet, and this is important for thinking about the Sixties as Jewish, when whites were asked to leave the SNCC in 1966, it began a rapid disentangling of Jewish involvement in AfricanAmerican Civil Rights.

By the 1960s public rhetoric described Jews as white. For nearly two decades Jews had been increasingly accepted in "white” society as white. They could no longer stand as racialized not-quite-whites with Blacks, working in an advocacy role for an even more racialized minority. While the rise of Black Power and African-American consciousness were instrumental in the exclusion of whites from Black organizations, the change in racial status of Jews also played a significant part. 
I have noted Brodkin arguing that the racialization of the Irish precursed that of the Jews in the mid-nineteenth century. In this she follows, as I will also, the foundational work of Noel Ignatiev in How the Irish Became White, a book the importance of which is signalled in its echo in the title of Brodkin's own book, itself groundbreaking. Spurred by the Great Famine of 1846-50, around 1.8 million Irish migrated to the United States between 1845 and 1855, almost a generation before the period of most significant Jewish migration. These Irish were predominantly poorer, Gaelic speakers and Catholic, as compared to earlier migrants from Ireland. In England, the colonising power, the Irish were increasingly racialized through the nineteenth century. Mostly, this took the form of associating their features with those of black Africans, and, with the acceptance of evolutionary theory which allowed for scientific claims to be made for a racial hierarchy, with apes. Physiognomy, a science in its own right, enabled commentators to focus on perceptions of the physical features of the Irish rather than their whiteness. As L. Perry Curtis jr. puts it: "Whether seen from a scientific, social, or cultural perspective, the Victorian images of the Irish as "white Negro" and simian Celt, or a combination of the two, derived much of its force and inspiration from physiognomical beliefs."49 In the United States, where, unlike England, there was a large population of enslaved and free black Africans, this understanding of the Catholic Irish as Negroid was acted out. Ignatiev writes that: "On their arrival in America, the Irish were thrown together with black people on jobs and in neighborhoods." ${ }^{50}$ He notes that this led not only to sexual relationships and children but also to a more general, dense web of everyday relations including shared participation in theft and an intermixing in church matters. $^{51}$

Ignatiev sums up this positioning of the Irish, writing that: "Strong tendencies existed in antebellum America to consign the Irish, if not to the black race, then to an 
intermediate race located socially between black and white.”52 Ignatiev argues that we cannot understand the whitening of the Irish without acknowledging that:

White supremacy was not a flaw in American democracy but part of its definition, and the development of democracy in the Jacksonian period cannot be understood without reference to supremacy. As it became the pillar of the Democratic party, Jeffersonian reservations over slavery and willingness to entertain notions of natural human equality (expressed in his Notes on Virginia) gave way to militant racial ideology. ${ }^{53}$

We can, by the by, place the Jewish second generation's championing of American democracy, something central to Reform Judaism, in this context. Elsewhere I have discussed Horace Kallen's - the main ideologue of cultural pluralism between the two world wars-complete lack of interest in the place of Blacks in American society. ${ }^{54}$ Jewish involvement in the Civil Rights movement, with its faith in the American democratic process can be contextualized in the third generation's increasingly certain, though still ambivalent, sense of themselves as "white.”

The racial nature of American democracy meant that:

In the combination of Southern planters and the "plain Republicans" of the North, the Irish were to become a key element. The truth is not, as some historians would have it, that slavery made it possible to extend to the Irish the privileges of citizenship, by providing another group for them to stand on, but the reverse, that the assimilation of the Irish into the white race made it possible to maintain slavery. The need to gain the loyalty of the Irish explains why the Democratic Party, on the whole, rejected nativism. ${ }^{55}$ 
At least at the political level, the whitening of the Irish had to do with a conservative attempt to preserve slavery. It was the second generation Jews, we can add, who turned to the Democratic Party in the 1920s and 1930s. As Moore writes, "Jews found the liberal Democratic blend of social reform and internationalism a compelling combination."56 We should remember that this was also the era when Jewish leaders were pushing the doctrine of cultural pluralism. The continuity in the Democratic Party lies not in its liberalism but in its recognition of the importance of enlisting minority groups in its support. This pragmatic concern with minorities led the party to a liberal, reformist agenda. Nevertheless, this may well have been a contributing factor to the third generation's disillusion with liberalism and party politics.

The whitening of the Irish, which was also played out in the union movement where, as Ignatiev writes, “[o]n the docks, the Irish effort to gain the rights of white men collided with the black struggle to maintain the right to work, ${ }^{, 57}$ took place through the final decades of the nineteenth century. The politicization of the Irish, albeit in a radical rather than conservative manifestation, appears in the Irish contribution to SDS and the Diggers but what underlies this, as it does for third generation Jews, is an anxiety over racial designation.

Brodkin makes the important distinction between ethno-racial assignment and ethno-racial identity. ${ }^{58}$ The Irish, like the Jews, may have been reassigned by American society as "white," but, in terms of identity, of self-conception, they were not so certain of their whiteness. In his memoir, Hayden links his Irish background to his radical politics:

The qualities I most liked in my parents - my father’s irony, my mother’s warmth, their resentment of elites, their gut populism—might well be the remnants of their ethnic heritage, while what disturbed me-their desire for acceptance, their civil 
obedience, their difficulty in embracing a radical son-represented the lures of assimilation. $^{59}$

At the least the resentment of elites and the gut populism, as well as the "negative qualities," can be sheeted home to the effects of social exclusion. Hayden, himself, remarks: “Now I grasped, for example, why in my experience Jews were the most liberal 'whites' in American society. It was because they remained the least assimilated, the most sensitive to the experience of oppression.”60

Hayden comments on his search for the context of his own radicalism:

I was trying to understand how the various Haydens, Garitys, Foleys, and Duceys were driven by a combination of desperation and hope to seek their [sic] identities as Americans, how their Irish ethnicity had been dissolved over a century and replaced by the bland, middle-class American identity of my parents. Not only was this new identity lacking in cultural richness, but I realized that its attainment involved an erasure of a historical consciousness of having once been oppressed. ${ }^{61}$

In a colonial irony, Hayden's attempt to visit his Irish origin failed when American authorities informed Irish officials that he was coming and they, fearing that he was going to Northern Ireland with the Irish Republican Army to agitate, put him back on a plane to New York. Hayden here repeats the dominant assumption, that upward social mobility into the middle class offers members of a group a universalist ideology that would replace the specificity of culture and erase any sense of racial difference-Hayden uses the term “ethnicity,” which presumes the Irish were thought of as white, something we know not to have been the case. Hayden's radicalism, and that of others of Irish descent in the sixties, suggests an ongoing unsettlement albeit more or less unconscious, founded on their problematic sense of racial identity. 


\section{Diggers, Yippies and “Guerrilla Theater"}

The Diggers mutated out of the San Francisco Mime Troupe in 1966. The Mime Troupe had been founded by R. (Ronnie) G. Davis in 1959. Davis, a New Yorker like some of his troupe, wanted to offer radical theatre that would make the audience "question its assumptions about politics, society and their lives.”62 To this end, Davis utilized the form of the sixteenth-century commedia dell'arte:

Masked stock characters such as Pantalone, Arlecchino, and Dottore were recognizable types distinguished by their exaggerated personalities: crankiness, ebullient foolishness, and pomposity. These archetypes had been lovingly researched and resurrected by the troupe to serve radical agit-prop theater. The company spoofed hypocrisy, misuse of power, and official venality with barbed wit, sexual innuendo, and gusto. ${ }^{63}$

Peter Berg, along with Coyote and Emmett Grogan decided to leave the Mime Troupe to pursue a more radical, activist theatre. All three came from the New York area, Berg and Coyote (born Peter Cohon) were both Jewish. Berg came from a radical family. Grogan, born Eugene Grogan, was of Catholic Irish background. ${ }^{64}$ Gitlin writes that "he and Billy Murcutt [another Digger] were working-class Irish boys from Brooklyn.”65

Davis remarked that: "I personally like to work with the kooks, the emotionally disturbed, the violent ones, the fallen away Catholics, non-Jewish Jews, the deviates. . . They do what the well-trained actor can never do-they create.”66 What can Davis mean when he says that these groups create? And what do lapsed Catholics and non-Jewish Jews have in common, and in common with the other groups Davis identifies? The key here is that lapsed Catholics, for which read lapsed Catholic Irish, and non-Jewish Jews are, as individuals, practising assimilation, learning to blend in with the dominant 
culture's everyday life. We could say that they are practising whiteness. The other groups Davis mentions are all composed of people defined out of the "normal,” everyday life of the dominant, all people who must learn to pass to be accepted, and all people who, in the nature of their affiliations, experience everyday life as problematic-something uncertain.

If Davis wanted to use these people to undermine the audience's assumptions, Peter Berg and his colleagues wanted a theatre that transformed everyday life, that took the migrant's and the excluded's preoccupation with the acting of the assimilatory process and used it to critique the established social order. It should not be a surprise that the Diggers were driven by a concern with social justice; that their emphasis on "free," for example shops where the goods were free, was a critique of the inequities of American capitalism. The Diggers' name was taken from the English seventeenth century radicals of the same name led by Gerard Winstanley. They are often viewed as precursors of the socialist tradition, an allusion that allows us to recognize an echo of the concerns of the first generation's socialism. ${ }^{67}$

Berg described the kind of theatre he wanted:

Theater as breaking glass ... the convention of theater [as] sitting in an audience watching a play was like the convention of being a member of society watching television, or cop-opera . . . the enforcement of society . . . If you broke the glass people would stream through to the other side of the stage and become life-actors. That's the whole riff. ${ }^{68}$

Equally, Berg could have described the convention of theatre as being like a member of society watching somebody learn to pass or assimilate into that society. In this Berg was describing the experience of his parents' generation. It is not coincidental that the most 
significant 1960s American sociologist of how people lived everyday life was the Jewish Erving Goffman, and his key theoretical conceit for critically engaging with the practice of daily life was the theatre and the notion of performance. ${ }^{69}$ Berg wanted to take that migrant experience to the non-migrants and non-excluded to, we might say, white America, and force them to experience life as a performance. Berg's insight was to understand the radical potential in this assimilation process.

Coyote writes that:

The phrase "life-actor" was Peter's contribution, describing a person who consciously creates the role he or she plays in everyday off-stage life, a person who marshals skill, imagination, and improvization in order to break free from imposed roles and restrictions and, by example, demonstrate a path that will free others. $^{70}$

The Diggers' most successful literalization of this idea in performance involved the erection of a twelve foot square wooden "Free Frame of Reference," painted yellow, at the intersection of Haight and Ashbury Streets in San Francisco. In addition people were given three inch square Frames of Reference to look through. Thus, people could look through their own Frame of Reference at other people walking through the Frame of Reference. $^{71}$

Abbie Hoffman's activist career can be broadly divided into two sections. The first encompasses his work for the Civil Rights movement which ended when he, along with all other "whites," was excluded from the SNCC in December 1966. The second included his "guerrilla theatre" which was inspired by the Digger performances in San Francisco, his involvement in the anti-Vietnam War movement and his co-foundation of the Yippies. ${ }^{72}$ From a Jewish perspective, Hoffman's activist career is marked by the 
Jews' shift of status from ambiguous racialization to marginalized whiteness. Immediately after the exclusion Hoffman published a highly emotional article in Village Voice, entitled "SNCC: The Desecration of a Delayed Dream," expressing his anger and sense of betrayal. Hoffman personalized the experience writing that his anger was "the kind of anger one might feel, say, in a love relationship, when after entering honestly you find that your loved one's been balling someone else, and what's worse, enjoying it.,73 What underlies this simile is Hoffman's sense of an altered reality, of a loss of the position by which he lived his life.

This article marks a watershed for Hoffman. It is the first in which he identifies his authorial self as "Abbie” rather than his given name of "Abbott.” We can note here that the Jews, and the Irish-background Diggers, of the counterculture often changed their names, from Peter Berg known as "the Hun” through to Robert Zimmerman, Bob Dylan. Name-changing was a part of Jewish attempts at assimilation and reflected a more or less unstable identity. In the Sixties it could have elements of these but it was also radicalized, becoming a statement about a person's change of identity and, in the hands of the Diggers, a more general statement about the modern association of individual identity with a person's name.

In addition to changing his name, here it would seem a break with his activist past but not with his family signalled by his keeping his family name, Hoffman also began to foreground his Jewishness, more specifically his Yiddishness. Raskin, himself Jewish and at one time putative Minister for Education for the Yippies, writes:

The expulsion of whites from SNCC made him feel naked and ashamed; indeed, he felt "like a schmuck." Abbie had grown up listening to his relatives speak Yiddish, and among friends he would toss out Yiddish expressions, but this was the first time he had used Yiddish in print. In years to come he would introduce 
Yiddish expressions into the movement at large, injecting a Jewish identity into radical politics. ${ }^{74}$

One way of reading this shift is that, in his Civil Rights phase, Hoffman, and other Jews, strove for whiteness by comparison with the Blacks on whose behalf they were struggling. Within whiteness, however, Jews asserted their difference as a way of preserving their identity.

Hoffman's first, and most famous, piece of guerrilla theater took place at the New York Stock Exchange on 24 August 1967. There is some debate about whether Hoffman called the media, in both Revolution for the Hell of It and Soon to be a Major Motion Picture he denies it but, according to Raskin, others remember differently. ${ }^{75}$ In the event, the performance became a media spectacle. Where the Diggers affected to despise television, Hoffman, who claims in Soon to be a Major Motion Picture that he learnt how to use the media for his own purposes from Marshall McLuhan's Understanding Media, ${ }^{76}$ merged spectacle and revolution. ${ }^{77}$ Where Berg and the Diggers wanted to incite people to perform, Hoffman understood that the pervasiveness of television meant that everything already was a performance. ${ }^{78}$ What he was after was spectacle.

Hoffman turned up at the Stock Exchange accompanied by Jerry Rubin and a dozen or so others. They lined up along with tourists waiting to take the official tour. When the captain of the security force hesitated to let them in calling them hippies, Hoffman, using his Jewishness as a weapon in this white, Anglo-American world replied “Who's a hippie? I’m Jewish and besides we don’t do demonstrations, see we have no picket signs.” On entering the visitors' gallery the group started throwing dollar bills onto the floor of the exchange. On the floor there was a scramble for the money. When the group were ushered out they were confronted by print and television journalists. ${ }^{79}$ 
This action, with its New Testament connotations of Jesus' confrontation with the moneylenders in the temple, works as a social justice-based critique of capitalistic avarice.

Hoffman and Rubin were also both involved in the planning of the anti-Vietnam War demonstration in October 1967. It was Rubin's idea to hold the protest at the Pentagon. ${ }^{80}$ The demonstration consisted of both a conventional rally and guerrilla theatre, the most important aspect of which was an exorcism and ceremony to levitate the building. While the Pentagon protest was extremely successful both in terms of numbers attending and media coverage, the event which changed the way most Americans understood television was the Yippie Festival of Life held at the Democratic Convention in Chicago during August 1968. Key to this change was the televised brutality of the Chicago police in their attacks on the demonstrators. ${ }^{81}$

This is not the place to detail the Pentagon and Chicago performances, nor to document the invention of the non-party, Yippie, other than to make the point that in all cases third generation Jews, in addition to Hoffman and Rubin, occupied a high percentage of leadership roles. Thus, for example, at the foundation of Yippie, as well as Hoffman and Rubin, there were Paul Krassner, Stew Albert and Phil Ochs. ${ }^{82}$ Robin Morgan, later better known as a feminist activist, was one of the Jewish women involved. Morgan was also one of the founders of WITCH, along with Sharon Krebs and Nancy Kurshan: Women’s International Terrorist Conspiracy from Hell. ${ }^{83}$ The point I want to make here about these people, about the personas they presented which merged with the performances they undertook, is that they lacked civility. Their disruption was, at bottom, a public unsettling of the civility which orders American sociality. Cuddihy argues for the importance of the Eastern European Jewish confrontation with modern civility in understanding the position of Jews in the nineteenth and twentieth centuries. 
He describes how the Jews' lack of civility, and therefore the failure of western people's attempts to develop reciprocally civil interactions with Eastern European Jews:

spread shock waves through nineteenth-century society. In arguing a larger alienation—since the norms of civility merely spell out and specify for face-toface interaction the more general values of the culture-the failure of civility came to define "the Jewish problem" as this problem reconstituted itself in the era of social modernity. ${ }^{84}$

It was this culturally inherited lack of civility which enabled Berg, Coyote, Hoffman, Rubin, and others to engage in uncivil public performances with such sophistication. And it was the white, Anglo-American preoccupation with civility which made these performances so effective.

When Rubin was subpoenaed to appear before HUAC in 1966 he took advice from R.G. Davis and wore the uniform of a 1776 American revolutionary soldier. ${ }^{85}$ Rubin wrote that: "I felt that to take the committee seriously would be devastating.,"86 Rubin's uncivil gesture simultaneously undermined the formality of the hearing and asserted his Americanness. In October 1968 many of the left-radicals including Hoffman, Rubin and Hayden appeared before HUAC. This time:

Jerry Rubin wore a bandolier of live cartridges and carried a toy M-16 rifle. Abbie appeared in a tie-dyed T-shirt with two feathers in his long hair. [The women of WITCH] carried brooms and wore black dresses and black hats. Forming a circle around Jerry, they burned incense, danced, and chanted. ${ }^{87}$

Hoffman and Rubin's lack of civility in the formal settings of the HUAC hearings extended to the Chicago Conspiracy Trial where they were charged, along with Dave Dellinger, Tom Hayden, Rennie Davis, John Froines, Lee Weiner and the Black Panther, 
Bobbie Seale with conspiring to commit offences against the United States. The trial was lengthy and constantly disrupted in uncivil ways. To stop him interrupting, Seale's mouth was taped and his hands and feet were shackled to a chair. Finally, the judge severed Seale's case from that of the others. The judge, Julius Hoffman, was a Jew descended from the earlier, nineteenth century, migration. A liberal, he was also highly assimilated and, from where Hoffman and Rubin stood, on the side of those in power. As Raskin puts it:

Abbie cast himself and his co-defendants as the "good Jews" and Julius Hoffman and Richard Schultz [the chief prosecutor] as the "bad Jews,” who were betraying their own people to the men of German ancestry in power in the White House: Henry Kissinger, Richard Kleindienst, H.R. Haldeman, and John Erlichman. ${ }^{88}$

Abbie began his testimony by making a point about the name he shared with the judge. When asked his last name he replied "My slave name is Hoffman. My real name is Shapoznikoff.” ${ }^{89}$ Abbie knew that his Russian forebears had been called Shapoznikoff. However, as part of their attempt to get to the United States they had acquired the papers of a German Jew called Hoffman. Abbie’s paternal grandfather adopted this name during his travels to the United States. Here we see another example of the mobility of names and identities to which, Jews, in particular, have been subject. Calling Hoffman a slave name, Abbie makes a connection between the difficulties of his own Eastern European Jewish family's migration with the forced transportation of Blacks as slaves when their owners took the right to (re)name them. By association, describing Hoffman as a slave name also attacked Julius Hoffman as an assimilated member of the establishment.

Five and a half months later, at the end of the trial, to the judge's horror, Dellinger shouted "bullshit" at the testimony of the deputy chief of the Chicago police. Davis and Rubin then repeated the word and Abbie followed it up with: "You are a disgrace to the 
Jews. You would have served Hitler better. Dig it."90 Abbie begins with the classic Jewish put-down, one which simultaneously acknowledges the Jewish community and suggests anxiety in a Gentile world. He follows this up with an indirect reference to what was just beginning to be called the Holocaust, associating Julius Hoffman with Hitler and, thereby, once more indicting Hoffman's German-Jewish heritage. On the following day Abbie took this attack further, saying to the judge:

"Your idea of justice is the only obscenity in the room. You schtunk. Schande vor de goyim, huh?”

The Court: "Mr Marshall, will you ask the defendant Hoffman to—“

Mr Hoffman: "Tell him to stick it up his bowling ball. How is your stock doing, Julie? You don’t have any power. They didn’t have any power in the Third Reich either."91

Rubin follows this up, accusing the judge of equalling Adolf Hitler. Abbie's manoeuvre is to assert his greater Jewishness by speaking Yiddish. He refers to the judge as a capitalist and feminizes him. All in all, Abbie attacks the judge as a class and community traitor.

Abbie's loathing of the judge is founded in the judge's assimilation, a possibility not offered the racialized Eastern European Jewish migrants and not acceptable to the whitened third generation who, unlike the German Jews who migrated roughly two generations earlier, grew up knowing from the death of relatives in the Holocaust, the impossibility of assimilation. The judge may think he has power but, as Abbie suggests, he doesn't really, he only has power as long as the white Americans allow him to exercise power. That the Chicago Conspiracy Trial judge was German-Jewish allowed Hoffman to express a double anger. It merges his anger as a radical at the organization of 
American society and its lack of social justice with his anger as a Jew, expressing his disappointment in the way Jews-his, Yiddish-background, Eastern European Jewshave been positioned in that society.

\section{White but not Acceptable}

I have already noted that Jacobson suggests that the whitening of the Jews began in the second half of the 1920s. Brodkin argues that this whitening took place after the Second World War. She explains the change as a combination of cultural changes, for example “[a]nti-Semitism and anti-European racism lost respectability,"92 and economic prosperity

which enabled Jews and other Euro-ethnics to enter the expanding white middle class. ${ }^{93}$ Both Jacobson and Brodkin are right. The expansion of whiteness was a long, slow and incomplete process. Moreover, as Brodkin writes: “Jews had a justifiable wariness about the extent to which America's embrace was real. They also had qualms about the costs of joining the mainstream to a Jewish sense of personal and social morality."94

Even as Jews were whitened, they were not regarded as the same as AngloAmerican whites. Prell tells us that:

In the decades following World War II, although antisemitism appeared to be waning, Jews' new affluence did not bring them the social and cultural acceptance that they anticipated from middle-class non-Jews. To the contrary, suburbs fostered the conviction that Jews were different, and Jewish women and their children became icons of excess and consumption. ${ }^{95}$

While Jews "rested firmly within the color line of their suburban neighbors,"96 "sociological studies learned that non-Jews left the suburbs when Jews moved in because they thought that Jews and their children were undesirable.”97 Prell writes that: "On the basis of a variety of community studies published in the early 1960s, it appeared that Jews 
were not finding interaction with their new neighbors at all easy."98 Jews complained that non-Jews made them feel unwelcome and wouldn't socialize with them.

Betty Friedan, born in 1921 and technically too old to be thought of as a Sixties radical, lived in this suburbia and published The Feminine Mystique in 1963. In that book, which kick-started second wave feminism, Friedan offers an extended simile of the suburban housewife as a Holocaust victim:

I am convinced there is something about the housewife state that is dangerous. In a sense that is not as far-fetched as it sounds, the women who "adjust" as housewives, who grow up wanting to be “just a housewife”, are in as much danger as the millions who walked to their own death in the concentration camps-and the millions more who refused to believe that the concentration camps existed. ${ }^{99}$

The anxiety born of the awareness of the Nazi genocide, as yet still unspoken and unnamed, formed a threnody that weaves its way through the Jewish concern with social justice which helped produce the social radicalism, in all its forms, of "the Sixties." I have noted Hoffman's reference to it, we can also note, for an example, that Dylan touches on it in "Talkin John Birch Paranoid Blues” off his first album, Bob Dylan (1962). Speaking as a member of the far-right John Birch Society he says:

Now we all agree with Hitler's views,

Although he killed six million Jews, It doesn't matter too much that he was a fascist, At least you can't say that he was a communist!

In Friedan's case, the metaphorical use suggests Friedan's greater than average, that is, greater than white women's, horror at the situation in which post-war middle-class women found themselves. In the 1930s Friedan's father referred “to the common 
phenomenon of five o'clock friends. Mr Goldstein told Bettye that socially prominent Christians would simply not talk to him after business hours.”100 Jews may have become whiter but otherwise things hadn’t changed much in suburbia by the early 1960s.

\section{The Feminist and Protest Movements}

The second wave women's movement grew out of a confluence of disillusions. The importance of Jewish women is indisputable. Joyce Antler, writes:

Like Friedan, many of the leaders and theorists of the 1960s feminist movement had been Jews, albeit largely secular, unidentified ones. Bella Abzug, Phyllis Chesler, Letty Cottin Pogrebin, and Vivian Gornick—as well as the half-Jewish Gloria Steinem—all played prominent roles in spearheading women's rights in the 1960s and early 1970s. Shulamith Firestone, Robin Morgan, Meredith Tax, Andrea Dworkin, and Naomi Weisstein were among the Jewish women active in the more radical wing of feminism—women's liberation. ${ }^{101}$

White women in general, as we have seen, were disillusioned with the life that they had been given to lead in the new suburbs. Promised so much, this life turned out to be lonely and spiritually empty. How much more disillusioned were Jewish women who had struggled to be accepted as white, had been only half-heartedly successful, and found themselves even more isolated and restricted in the suburbs than their WASP peers. That, as Antler points out, so many of these women were secular and non-identifying Jews, suggests the high degree of assimilation of these women into an American society that only half-heartedly accepted them. Antler adumbrates other reasons: Friedan's suggestion that the high level of education among Jewish women increased their sense of frustration; Anne Roiphe's idea of the importance of Jewish women's disgust at the way they were portrayed in the media, and by Jewish men. 
For the Sixties generation themselves there was another disillusion. As Antler tells it:

By 1967, many [activist women] had become outraged at their treatment by male radicals whose belief in freedom and equality apparently only applied to men. After their attempts to introduce women's issues into the movement were met with ridicule, these women began to organize groups of their own, identifying their cause as women’s liberation. "The personal is political” became their slogan and consciousness-raising their primary tool. ${ }^{102}$

We can hypothesize that one reason why so many male radicals were against—or, perhaps, at the least, could not understand-the concerns of these women was that they came from Jewish households which, religious or secular, continued the Jewish patriarchal tradition. A reason for the high level of anger of these politicized women was that, as Jews, they too came from just such households. That the personal is political would have been particularly obvious to these women.

If the Jewish women who played such an important part in the founding of both second wave feminism and women's liberation were ambivalently assimilated, then we can say the same for those Jews who played such an important role in the development of the so-called "protest movement” in folk music. At the moment when folk music ceased to be identified with roots music and with a socialism that celebrated the rural workers and became the radical aspect of commercial popular music, a number of third generation Jewish singer/songwriters found in this musical form an ideal way to express their concerns about social justice.

In the early part of the twentieth century folk music was constructed as essentially white and American. Benjamin Filene writes that: 
Mostly white Anglo-Saxon Protestants, the song collectors asserted that [Appalachian] mountain culture was America's authentic folk inheritance and at the same time stressed that the mountaineers were British. In effect, therefore, the collectors established their heritage as the true American culture. ${ }^{103}$

The tradition with which Bob Dylan identified flowed from Woody Guthrie through Pete Seeger. Prior to Dylan, however, there was Ramblin’ Jack Elliott. Elliott, born Elliott Charles Adnopoz in 1931, was the son of a Jewish doctor in Brooklyn. The story goes that at age fourteen, enamoured of the cowboy life, he ran away from home to join a rodeo. Returning to New York he became friendly with Woody Guthrie, learning his style of guitar playing and singing. Guthrie, born in 1912, the most outspoken of the folksingers of his Pre-World War II generation, revolutionized folk music as an overtly politically committed musical form. ${ }^{104}$ Given his concern with social justice it is understandable that Guthrie's second, and long-term, marriage was to the Jewish Majorie Mazia. Their children, including the Sixties folk singer, Arlo, were brought up as Jewsin the late 1950s Arlo was tutored in Judaism by a then unknown rabbi named Meir Kahane. Ramblin' Jack travelled the country with Guthrie for around five years. The point here is about the complexities of assimilation. Ramblin' Jack's change of name signals his attempt to Americanize himself and downplay his Jewish background. His fantasy about being a cowboy was quintessentially Anglo-American (we should remember Jerry Rubin’s cowboy fantasy here), as was his liking for folk music. At the same time, his friendship with Woody Guthrie shows his belief in social justice which, as we have seen, is a central part of the Jewish-American tradition. ${ }^{105}$

The commercial breakthrough of folk music came with the 1958 release of The Kingston Trio’s soft-folk version of “Tom Dooley.” Robert Cantwell, in When We Were Good, places this moment in context: "The folk revival . . . is really a moment of 
transformation in which an unprecedented convergence of postwar economic and demographic forces carried a culture of personal rebellion across normally impermeable social and cultural barriers under the influence and authority of folk music, at once democratic and esoteric, already imbued with the spirit of protest.”106 One of the more successful of the soft-folk groups who formed in the wake of the Kingston Trio's hit was The Limeliters. Another trio, it included Lou Gottlieb. Gottlieb was Jewish. Needless to say, he was the comic of the group. After he left the group in 1965, he lived on a farm he called Morningstar that he had bought north of San Francisco. There, Gottlieb founded a commune and supplied organic fruit and vegetables to the Diggers for their free food program. Gottlieb's life is one of the examples of the interconnections across different facets of cultural and political life in the Sixties. The thread through his life is typically Jewish-American—consciously or not, it explores the problem of how to find a way of living that practiced social justice. As I have explained, such a concern very often emanated from Jewish family backgrounds. Peter Yarrow, of Peter, Paul and Mary, is typical in this regard. Born in 1938, he has said that: "His family . . ' 'placed a great emphasis on ethics, values and culture.' They also seem to have placed a high value on the arts and scholarship.”107 It almost goes without saying that Woody Guthrie was one of Yarrow's idols.

However, Bob Dylan was the most important social commentator and critic, Jewish or not, to come out of the folk music scene of the late 1950s and early 1960s. Dylan, born Robert Zimmerman in 1941, came from a middle-class Jewish background in the small town of Hibbing, Minnesota. His parents moved there from Duluth, also in Minnesota, when he was six. Dylan tells a story about how he took lessons for his barmitzvah in 1954 from a rabbi who lived upstairs from the local rock’n'roll café. Dylan would first see the rabbi and then hang out in the juke joint. Dylan's great-grandparents 
on his mother's side migrated from Lithuania to North Hibbing in 1902. On his father's side, Dylan’s grandparents moved from Odessa to Duluth in 1907.

In September 1959, Dylan moved from Hibbing to Minneapolis where he had a place at the University of Minnesota. He lived in a Jewish fraternity house. ${ }^{108}$ At the same time he started erasing the signs of his Jewishness. Asking for a gig at The Ten O’Clock Scholar, he called himself Dylan. ${ }^{109}$ Traditionally, this is seen as a reference to that great wordsmith Dylan Thomas. It places Dylan in the Anglo poetic tradition. We need to remember, though, that Dylan Thomas wasn't English, he was Welsh. Here we have an example of the ambiguity that runs through Dylan's work. He didn't express himself as fully Anglo-American even when he was downplaying his Jewishness.

Dylan's hero was also Woody Guthrie. However, by the time he came to meet the man himself, Guthrie was too sick with Huntington's Chorea to be able to tutor Dylan. Much of what Dylan learnt about singing and playing in the vein of Guthrie came from Ramblin’ Jack. As Ramblin’ Jack has said: “Dylan learnt from me the same way I learned from Woody. Woody didn’t teach me. He just said, 'If you want to learn something just steal it—that's the way I learnt from Leadbelly."”110 There is a, perhaps apocryphal, story that Dylan found out that Ramblin’ Jack was Jewish one day when they were both driving in a car and that Dylan reaction was to throw Jack out of the car. Dylan was disappointed at Ramblin' Jack’s lack of authentic Americanness—something that, of course, Dylan was himself trying to learn.

In this early period Dylan effaced his Jewishness in favour of an all-American rural, if not cowboy, background. In Writings and Drawings, published in 1973, Dylan offers a short, poetic autobiography entitled "My Life in a Stolen Moment."111 Here he describes being born in Duluth and writes that: "My mother's from the Iron Range Country up north.” Not incorrect, but not the whole truth either, this statement suggests 
Dylan as having that Midwest rural Anglo heritage that would authenticate him as a “real” American.

The complexities of Dylan's ambivalent relation to his Jewishness while assimilating into white America is best expressed in a brief song Dylan started including in his set in 1961 after he got to New York. It’s called “Talkin’ Hava Negeilah Blues.” The recorded version has Dylan prefacing it with "Here's a foreign song I learnt in Utah.”"112 He then chants 'Ha! Va! Ha-va! Ha-va-na! Hava Nageilah!', following this with a yodel and then a harmonica riff typical of his blues-influenced numbers. Larry Yudelson, in his discussion of the Jewishness of Dylan's work. "Dylan: Tangled Up in Jews,” writes that:

With the yodel and a finishing harmonica flourish, Dylan had outlined an epitaph for the Hebrew folk songs sung by folksingers like Theodore Bikel and the Weavers as part of a vaguely leftist, working-man's ethnic repertoire. The mockery was prescient. The left would not be strumming love songs about Israeli soldiers much longer. Dylan, with his inspired instinct for the authentic, was first to smell the phoniness. ${ }^{113}$

While certainly there may be something satirical in Dylan's Americanized reworking of the Jewish/Israeli folk song, it also exemplifies the assimilative ambiguities that dogged the third generation and characterized the Sixties. Dylan brings together his claimed American heritage with his Jewish heritage, asserting the latter while framing the song with both an Appalachian-style yodel and a reference to Black American music. It is worth commenting very briefly on Dylan's “Utah” reference. Utah simultaneously signifies the American heartland and the slightly not-quite-typical Americanness of the Mormons. Again, then, even here, we have a degree of ambiguity, this time displaced from Jewishness to another, albeit American-originated, religion. 
In his study of “Jews and Rock and Roll,” E. Anthony Rotundo describes the lack of a Jewish presence in (pre-Glam Rock and punk) rock’n'roll. ${ }^{114}$ This was not the case in the folk/protest movement. In addition to the people I have already mentioned—and we should certainly not forget Phil Ochs who was one of the founders of the Yippies and who used his songs for years to sing out against the Vietnam War-there were others, such as Country Joe McDonald, who is of Scots and Jewish background. ${ }^{115}$ He came from a radical family and became involved in politics himself by way of the Free Speech Movement at Berkeley. He was the writer of what was, perhaps, the most well known anti-Vietnam war song, “I Feel Like I’m Fixin’ To Die Rag.”116 Barry Melton and Gary Hirsch, also from Country Joe and the Fish, are Jewish as are Jorma Kaukonen, Spencer Dryden and Marty Balin who used to play with another high profile countercultural San Francisco band, Jefferson Airplane. Then there were also Paul Simon and Art Garfunkel, both from Queens, whose earlier work resonated with the protest movement and whose later work chimed with the angst and disillusionment of (Jewish) middle-class youth on a more personal level.

For all these people the folk/protest movement offered a way of simultaneously identifying as American and offering a social commentary and critique, something born out of their Jewish family backgrounds and their sense of not quite fully belonging —not being allowed to assimilate fully_into Anglo-American society. Gitlin tells how Dylan turned up to SDS’s 1963 National Council meeting in the company of a Mississippi civil rights lawyer. Dylan indicated that he was interested in working on an ERAP (Economic Research and Action Project) and offered to sing benefit concerts for SDS. ${ }^{117}$ Neither of these things happened but that's not the point. Dylan here shows the cultural and political convictions that were typical of the third generation's rebellion against their parents too easy acceptance of American liberalism and the sacrifice of personal values that was the 
price they paid for the assimilation that, in the end, they were not fully granted. If much of Dylan’s early work dealt with issues associated with social injustice, then much of his later work deals with the ethics of personal life. I am thinking here of material on albums as diverse as Blood on the Tracks (1975) and Desire (1976) and the much later Time Out of Mind (1997) and Love and Theft (2001).

The American society in which the third generation of Jews grew up only partially accepted them as white. Many of those Jews who contributed to the average of 325,000 a year at colleges and universities in the early 1960s were lucky to be there. The more or less informal quotas on the number of Jews being allowed into institutions of higher education were gradually done away with after the Second World War ${ }^{118}$ — certainly an institutional sign of Jewish whitening. This was a world in which the expectations which had seemed so certain to the second generation appeared to have fallen short. The United States had not lived up to its claims to be a socially just society. To the third generation this was most obvious in the increasingly clearly unjust Vietnam War. However, in a more diffuse, yet more fundamental, way the recognition of the generalized lack of social justice in American society was the cornerstone of the counterculture and of the hippie critique. For the Jews that led these movements, there own lack of acceptance into middle-class white suburban society-the post-World War II American consumerist utopia_-grounded this understanding at a personal level.

Sixties' Jewish radicalism which, as we have seen, spread across all aspects of political and cultural life, was founded in the third generation's strong belief in social justice and their recognition that neither their mostly liberal, Democratic-voting Jewish parents nor American society itself lived up to the standards of social justice that were asserted in the syncretized value system of Jewish-American and (WASP) American life. The recognition of the always only ambivalent acceptance of Jews into American 
whiteness chimed with the experience of the Catholic Irish in the United States and helped to produce a similarity of perception which led to the primarily Jewish but also Catholic Irish-American dominance of Sixties radicalism. It is possible to read out of the epigram that I have taken from Dylan’s epic and densely allusive song of disenchantment, 'Desolation Row' (released on Highway 61 Revisited in 1965), a recognition of the problematic implications of Jewish assimilation, and its relation to social justice. As well, there can also be read an acknowledgment of the Catholic, by implication Irish, connection. It was the very repositioning of the Jews as white in the post World War II period, with all that promised, and with all that American ideology promised in the way of social justice, that produced the conditions for the radicalism of the third generation that underwrote Sixties radicalism more generally, when those promises were found to be illusory.

\section{Notes}

\section{Chapter Eight}

1. A relevant article on Sixties Jewish radicals is Anthony Ashbolt, "Prodigal Sons and Political Amnesia: American Radicalism, Jewish Identity, Israel,” Australasian Journal of American Studies 11.1 (1992): 15-26.

2. Jonathan Kaufman, Broken Alliance: The Turbulent Times Between Blacks and Jews in America (New York: Simon \& Schuster, 1988), 66.

3. Jonah Raskin, For the Hell of It: The Life and Times of Abbie Hoffman (Berkeley, CA: University of California Press, 1996), 75.

4. Arthur Liebman, Jews and the Left (New York: John Wiley and Sons, 1979), 67.

5. On the League for Industrial Democracy and its relations with Students for a Democratic Society see Todd Gitlin, The Sixties: Years of Hope, Days of Rage (New York: Bantam Books, 1987), 109-111 and James Miller, Democracy is in the Streets: From Port Huron to the siege of Chicago (Cambridge, Mass: Harvard University Press, 1994), Parts I and II, passim.

6. Liebman, Jews and the Left, 67. 
7. Liebman, Jews and the Left, 67.

8. Liebman, Jews and the Left, 67.

9. Liebman, Jews and the Left, 67.

10. Peter Collier and David Horowitz, Destructive Generation: Second Thoughts About the Sixties (New York: Free Press Paperbacks, 1996), 81. Ron Jacobs has written the history of the Weather Underground in The Way the Wind Blew: A History of the Weather Underground (London: Verso, 1997).

11. See Gitlin, The Sixties, 82-83.

12. Liebman, Jews and the Left, 68.

13. Liebman, Jews and the Left, 541.

14. Liebman, Jews and the Left, 68.

15. Liebman, Jews and the Left, 68.

16. Liebman, Jews and the Left, 543.

17. Arnold Eisen, The Chosen People in America: A Study in Jewish Religious Ideology (Bloomington: Indiana University Press, 1983), 8.

18. Eisen, The Chosen People, 6.

19. Nelson Glueck, quoted in Eisen, The Chosen People, 38.

20. Deborah Dash Moore, At Home in America: Second Generation New York Jews (New York: Columbia University Press, 1981), 150.

21. Moore, At Home in America, 149.

22. Moore, At Home in America, 11.

23. Dominick Gavallo, A Fiction of the Past: The Sixties in American History (New York: Palgrave, 1999), 72.

24. Liebman, Jews and the Left, 68.

25. Melanie Kaye/Kantrowitz, "Stayed in Freedom: Jews in the Civil Rights Movement and After," in The Narrow Bridge: Jewish Views on Multiculturalism, ed. Marla Brettschneider (New Brunswick, NJ:Rutgers University Press, 1996), 111.

26. Abbie Hoffman, Soon to be a Major Motion Picture (New York: Putnam, 1980), 15. 
27. Raskin, For the Hell of It, 117.

28. Cavallo, A Fiction of the Past, 70-71.

29. Riv-Ellen Prell, Fighting to Become Americans: Jews, Gender, and the Anxiety of Assimilation (Boston, Mass: Beacon Press, 1999), 159-160. The study to which she refers is Marshall Sklare with Joseph Greenblum Jewish Identity on the Suburban Frontier (Chicago: University of Chicago Press, 1979).

30. Miller, Democracy is in the Streets, 13.

31. Hayden's background is detailed in Miller, Democracy is in the Streets, 42-50.

32. Gitlin, The Sixties, 117.

33. Eisen The Chosen People in America, 55.

34. The Port Huron Statement is reprinted in its entirety in Miller, Democracy is in the Streets, 331.

35. Miller, Democracy is in the Streets, 332.

36. Eisen, The Chosen People in America, 51.

37. Cavallo, A Fiction of the Past, 74.

38. See "Making Space for Jews in America” in Jon Stratton Coming Out Jewish: Constructing Ambivalent Identities (London: Routledge, 2000).

39. Miller, Democracy is in the Streets, 94-95.

40. Arnold Kaufman, "Human Nature and Participatory Democracy," in Responsibility, ed. Carl J. Friedrich (New York: Liberal Arts Press, 1960), 272.

41. Cavallo, A Fiction of the Past, chapter 8 "The Political Ferment of the Late Eighteenth Century and SDS's Failed Quest for Community.”

42. Matthew Frye Jacobson, Whiteness of a Different Color: European Immigrants and the Alchemy of Race (Cambridge, Mass.: Harvard University Press 1998), 8.

43. Karen Brodkin, How Jews Became White Folks and What That Says About Race in America (New Brunswick, N.J: Rutgers University Press, 1998), 27.

44. Madison Grant, The Passing of the Great Race (Arno Press and the New York Times: New York, 1970), chapter ii "The Physical Basis of Race.”

45. John Murray Cuddihy, The Ordeal of Civility: Freud, Marx, Levi-Strauss, and the Jewish Struggle with Modernity (New York: Basic Books Inc., 1974), 4-7. 
46. Brodkin, How Jews Became White Folks, 109.

47. Kaufman, Broken Alliance, 21-23.

48. Kaufman, Broken Alliance, 25.

49. L. Perry Curtis, Apes and Angels: The Irishman in Victorian Caricature rev. ed. (Washington: Smithsonian Institution Press, 1997). See also Ann McClintock's discussion in Imperial Leather: Race, Gender, and Sexuality in the Colonial Conquest (New York: Routledge, 1995).

50. Noel Ignatiev, How the Irish Became White (New York: Routledge, 1995), 40.

51. Ignatiev, How the Irish Became White, 41.

52. Ignatiev, How the Irish Became White, 76.

53. Ignatiev, How the Irish Became White, 68.

54. Stratton, "Making Space for Jews in America,” in Coming Out Jewish.

55. Ignatiev, How the Irish Became White, 69.

56. Moore, At Home in America, 211.

57. Ignatiev, How the Irish Became White, 120.

58. Brodkin, How Jews Became White Folks, 3.

59. Tom Hayden, Reunion: A Memoir (New York: Random House, 1988), 433.

60. Hayden, Reunion, 433.

61. Hayden, Reunion, 432.

62. Cavallo, A Fiction of the Past, 117.

63. Peter Coyote, Sleeping White I Fall: A Chronicle (Washington, DC: Counterpoint, 1998), 12.

64. Emmett Grogan's autobiography is Ringolevio: A Life Played for Keeps (London: Heineman, 1972).

65. Gitlin, The Sixties, 223.

66. Davis quoted in Cavallo, A Fiction of the Past, 118.

67. On the seventeenth century Diggers see Christopher Hill, The World Turned Upside Down: Radical Idea During the English Revolution London: Temple Smith, 1972. 
Coyote himself refers to the principles of Winstanley's Diggers becoming "part of the basic tenets of the socialist tradition," Sleeping Where I Fall, 68.

68. Unreferenced quotation from Peter Berg in Coyote, Sleeping Where I Fall, 33.

69. See, for example Erving Goffman's book, The Presentation of Self in Everyday Life (New York: Anchor Books, 1959).

70. Coyote, Sleeping Where I Fall.

71. For descriptions of this event see Cavallo, A Fiction of the Past, 100; and Gitlin, The Sixties, 223.

72. Peter Berg invented the term "guerrilla theatre" to describe the work that R. G. Davis was doing with the San Francisco Mime Troupe. In The San Francisco Mime Troupe: The First Ten Years (Palo Alto, California: Ramparts Press, 1975), Davis writes: "I had written a long essay on the workings of the company and an analysis of what we had done in the past few years. The article was read to the company in May 1965, just as we moved from Capp Street in the Mission to our new large downtown loft on Howard Street. [Bill] Graham heard it and liked the toughness. [Peter] Berg understood it and called it "Guerrilla Theatre," 70. Graham was born Wolfgang Grajonza to Jewish parents in Berlin in 1931. After walking across France he reached Ellis Island in 1941. Graham's mother died on the journey to Auschwitz. (For Graham's biography see John Glatt, Rage \& Roll: Bill Graham and the Selling of Rock (New York: Carol Publishing, 1993)). According to Glatt's biography (chapter 3), Graham began his career in 1965 managing the Mime Troupe: “Davis, impressed with Graham’s fast-talking confidence and his obvious talents as a salesman, offered him the job as Mime Troupe business manager. Graham accepted on the spot with the proviso that he could bring his devoted girlfriend/secretary Bonnie MacLean along with him,” 26. Davis tells a different version of Graham's relation to the Mime Troupe: "Bill Graham, who was hired to help us tour from location to location (we had no stable theatre), had promoted himself to 'Bill Graham Presents' and was on the way out of our company when we went to the Northwest,” 58. Graham helped Ken Kesey run the celebrated Trips Festival in 1966 and went on to become the most important promoter of the new San Francisco sound, putting on bands at the Fillmore.

73. Quoted in Raskin, For the Hell of It, 76.

74. Raskin, For the Hell of It, 76.

75. Raskin, For the Hell of It, 114.

76. Abbie Hoffman, Soon to be a Major Motion Picture, 85.

77. In this, Hoffman was working in a similar manner to the Situationists in France. On the Situationists see Sadie Plant, The Most Radical Gesture: The Situationist

International in a Postmodern Age (London: Routledge, 1992). 
78. It could be argued that it was Hoffman's assimilatory background that sensitised him to the idea of performance and, therefore, to the way television transforms life into performance.

79. Accepting that Hoffman's accounts are unreliable, the most detailed version of the Stock Exchange event is to be found in Raskin, For the Hell of It, 114-117.

80. Raskin, For the Hell of It, 117.

81. See, for example, Norman Mailer's account of the Chicago confrontation in Miami and the Seige of Chicago: An Informal History of the American Political Conventions of 1968 (Harmondsworth: Penguin, 1969).

82. Sometime during this period Rubin and Hoffman start writing "America” as "Amerika." Certainly this is the way the country is written in Jerry Rubin's book, Do It! Scenarios of the Revolution (New York: Simon and Schuster, 1970). Norman Podhoretz, the right-wing Jewish-American commentator writes in his 1999 book, Ex-Friends: Falling Out with Allen Ginsberg, Lionel and Diana Trilling, Lillian Hellman, Hannah Arendt, and Norman Mailer (New York: Simon and Schuster, 1999), that: "What [Hoffman, Rubin, Dylan and others] all had in common was a fierce hatred of America, which saw as 'Amerika,' a country morally and spiritually equivalent to Nazi Germany,” 47. While there is truth in this, and it once more reminds us of how much the ghost of the Holocaust haunts the Jewish radicals of the sixties, we should, in addition, remember Amerika is also the Yiddish spelling and that the Jewish sixties, at some albeit deep level, can be traced back to the complicated reactions of this generation's grandparents who thought they were migrating to die golden medinah, the golden land.

83. On feminist guerrilla theatre see Robin Morgan’s piece, "Feminist Guerilla Theater, 1968," reprinted in Susan Ware ed. Modern American Women: A Documentary History, (Chicago: Dorsey Press, 1989), 341-344.

84. Cuddihy, The Ordeal of Civility, 3.

85. Rubin tells his version of this story in, Do It!, 58-65.

86. Quoted in Raskin For the Hell of It, 118.

87. Raskin, For the Hell of It, 177.

88. Raskin, For the Hell of It, 200-201.

89. The segment of Hoffman's testimony is reprinted in Larry Sloman, Steal This Dream: Abbie Hoffman \& the Countercultural REvolustion in America (New York: Doubleday, 1998), 204-205.

90. The segment of the trial is reprinted in Sloman, Steal This Dream, 211.

91. This segment of the trial transcript is in Sloman, Steal This Dream, 211-212. 
92. Brodkin, How Jews Became White Folks, 36.

93. Brodkin, How Jews Became White Folks, 37.

94. Brodkin, How Jews Became White Folks, 139.

95. Prell, Fighting to Become American, 144.

96. Prell, Fighting to Become American, 158.

97. Prell, Fighting to Become American, 158.

98. Prell, Fighting to Become American, 158.

99. Betty Friédan, The Feminine Mystique (New York: Dell Publishing, 1963), 305. The discursive connections between the second wave feminist movement and the Holocaust are complex. Many of these get invoked thirty-six years after The Feminine Mystique in Andrea Dworkin's tour de force, Scapegoat: The Jews, Israel, and Women's Liberation. It should go without saying that Dworkin, like Friedan and so many other second wave feminists, is Jewish.

100. Daniel Horowitz, Betty Friedan and the Making of the Feminine Mystique: The American Left, the Cold War, and Modern Feminism (Amherst: University of Massachusetts Press, 1998), 23.

101. Antler, The Journey Home, 260.

102. Antler, The Journey Home, 261.

103. Benjamin Filene, Romancing the Folk: Public Memory and American Roots Music (Chapel Hill: University of North Carolina Press, 2000), 25.

104. See Joe Klein, Woody Guthrie: A Life (New York: Alfred Knopf, 1980).

105. The record label devoted to the recording of American folk music, Folkways, was established by Moses Asch, the son of the Yiddish writer Sholem Asch (1905-1986), in 1948. Once again we have the connection between what is considered quintessentially American music and Jewish-Americans. Asch is said to have turned down the opportunity to record Dylan when he was looking for a record company.

106. Robert Cantwell, When We Were Good: The Folk Revival (Cambridge, Mass.: Harvard University Press, 1996), 346.

107 At: http://www.peterpaulmary.net/history/ruhlmann1.htm

108. The early biographies of Dylan, such as Anthony Scaduto, Dylan, An Intimate Biography (New York, Grosset \& Dunlap, 1971) tend to ignore Dylan’s Jewish background. Bob Spitz, Dylan: A Biography (New York: McGraw Hill, 1989), offers most constant attention to the Jewish aspects of Dylan's life and career. 
109. This information comes from Clinton Heylin, Bob Dylan: A Life in Stolen Moments (New York: Schirmer Books), 1996.

110. Quoted in Ramblin' Jack Elliott's biography at:

http://www.ramblinjack.com/bio2.html

111. Bob Dylan, Writings and Drawings New York, 1974, 49.

112. The song can be found on Bob Dylan, The Bootleg Series, Volumes 1-3, (1991).

113. Larry Yudelson, “Dylan: Tangled Up in Jews” at:

http://www.radiohazak.com/Tangled.html

114. E. Anthony Rotundo, "Jews and Rock and Roll: A Study in Cultural Contrast" American Jewish History 72 (1982): 82-107.

115. Personal communication.

116. For Country Joe McDonald's biography see:

http://www.countryjoe.com/cjmbio.htm\#1 The song “I Feel Like I'm Fixin' To Die Rag” was released on the second Country Joe and the Fish album entitled I Feel Like I'm Fixin' To Die released in 1967.

117. Gitlin, The Sixties, 198.

118. Marcia Graham Synnott, “Anti-Semitism and American Universities: Did Quotas Follow the Jews?” in Anti-Semitism in American History ed. David Gerber (Urbana: University of Illinois Press, 1986), 233-271. 